\title{
Effect of sulfonated block copolymer on the equilibrium and thermal properties of sulfonated fluoroblock copolymer blend membrane
}

\author{
Efecto del copolímero en bloque sulfonado sobre las propiedades térmicas y de equilibrio \\ de una membrana sulfonada mezclada con un fluoropolímero en bloque
}

\author{
Edward M. A. Guerrero-Gutiérrez*
}

Escuela de Ingeniería Química, Facultad de Ingeniería, Universidad de San Carlos de Guatemala

*Autor al que se dirige la correspondencia: edward.guerrero@upr.edu

\begin{abstract}
Recibido: 26 de marzo 2020 / Revisión: 02 de agosto 2020 / Aceptado: 29 de enero 2021

$\mathrm{P}$ olymeric membrane technologies demand the synthesis of new polymers to enhance their equilibrium, thermal, and transport properties. Therefore, the focus of this investigation was the evaluation of the equilibrium and thermal properties of a sulfonated fluoroblock copolymer blend membrane composed of sulfonated poly(styrene-isobutylene-styrene) (SIBS $\mathrm{SO}_{3} \mathrm{H}$ ) and a novel sulfonated fluoroblock copolymer composed of poly(4-fluorostyrene) (P4FS), poly(styrene) (PS) and poly(isobutylene) (PIB). The fluoroblock copolymer was synthesized using Atom Transfer Radical Polymerization (ATRP) and cationic polymerization. First, the molecular weight and the thermal stability of the block copolymer were determined using Gel Permeation Chromatography (GPC) and Thermogravimetric Analysis (TGA). Second, the chemical composition was monitored utilizing Fourier Transform Infrared spectroscopy (FTIR) and Nuclear Magnetic Resonance (NMR) spectroscopy. The molecular weight of P4FS-b-PS was $\mathrm{Mn} \sim 36,100$; this value increased $8 \%$ after the cationic polymerization. The equilibrium properties of the membrane were evaluated using the water uptake and Ion-Exchange Capacity. The degradation behavior and the thermal transitions were determined using TGA and Differential Scanning Calorimetry (DSC), respectively. This newly membrane exhibited water uptake higher than $608 \%$ related to the improvement of $36 \%$ in the ion-exchange capacity and the increment of $25.31 \%$ and $25.24 \%$ in the energy required to produce the thermal transitions induced by the addition of the sulfonated fluoroblock copolymer.
\end{abstract}

Palabras claves: Ion-Exchanged Capacity, DSC, thermal degradation, ionic domains

Resumen

T a tecnología de membranas poliméricas requiere de la síntesis de nuevos polímeros que mejoren sus pro-

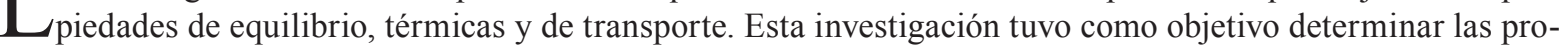
piedades de equilibrio y térmicas de una membrana compuesta de poli(estireno-isobutileno-estireno) sulfonado (SIBS $\mathrm{SO}_{3} \mathrm{H}$ ) y un fluoropolímero en bloque sulfonado compuesto de poli(4-fluorostireno) (P4FS), poli(estireno) (PS) y poli(isobutileno) (PIB). El fluoropolímero en bloque se sintetizó utilizando la técnica de polimerización radical por transferencia atómica (ATRP por sus siglas en inglés) y polimerización catiónica. El peso molecular y la estabilidad térmica del fluoropolímero en bloque fueron determinadas por medio de Cromatografía de Permeación en Gel (GPC) y un análisis termogravimétrico (TGA). La composición química se monitorizó utilizando espectroscopía infrarroja por transformada de Fourier (FTIR) y espectroscopía de Resonancia Magnética Nuclear (RMN). El peso molecular de P4FS-b-PS fue $\mathrm{Mn} \sim 36,100$; este valor aumentó un 8\% después de la polimerización catiónica. Las propiedades de equilibrio de la membrana fueron evaluadas por medio de la absorción de agua y la capacidad de intercambio iónico. El comportamiento de degradación y las transiciones térmicas se determinaron utilizando TGA y Calorimetría Diferencial de Barrido (DSC). Esta nueva membrana exhibió una absorción de agua mayor del $608 \%$ relacionada con la mejora del 36\% en la capacidad de intercambio iónico y el incremento en $25.31 \%$ y $25.24 \%$ en la energía requerida para producir las transiciones termales inducidas por la adición del fluoropolímero sulfonado en bloque.

Keywords: Capacidad de intercambio iónico, DSC, degradación termal, dominios iónicos 


\section{Introduction}

Membrane technologies are characterized by simultaneous retention of species and product flow through the semipermeable membrane. Membrane performance is based on its high selectivity, compatibility with the operating environment, good mechanical, chemical, and thermal properties (Singh, 2015). These technologies possess several advantages over conventional separation processes: environmentally safe, easy to operate and produce high-quality products (Ahmad \& Ahmed, 2014). The most widely employed membrane technologies applications are gas separation (Ye et al., 2019), water purification (Madaeni et al., 2015), chemical-biological protecting clothes (Barreto $\&$ Suleiman, 2010), and proton exchanged membranes (PEMs) fuel cells (Avilés-Barreto \& Suleiman, 2013; Pérez-Pérez \& Suleiman, 2016; Xie et al., 2015). PEMs fuel cells are electrochemical devices that convert chemical energy of the reactants directly into electricity and heat with high efficiency (Alaswad et al., 2016). This device consists of a cathode, an anode and an electrolyte membrane (Peighambardoust et al., 2010). Nafion $\AA$ is a sulfonated fluoropolymer that is the state-of-the-art membrane in PEMs applications because of its high proton conductivity and excellent thermal and mechanical properties (Mauritz \& Moore, 2004). Nafion ${ }^{\circledR}$ morphology plays an important role because is modify by the hydration process, which results in growth and connectivity of the hydrophilic domains that enable facile proton and water transport (Kusoglu \& Weber, 2017). Unfortunately, this membrane possesses several disadvantages, such as its high cost to manufacture and low conductivity under low humidity conditions (Kraytsberg \& Ein-Eli, 2014; Santoro et al., 2017).

Sulfonated poly(styrene-isobutylene-styrene) ( $\mathrm{SIBS}_{3} \mathrm{H}$ ) is a sulfonated thermoplastic elastomer that has attracted attention as an alternative PEMs membrane due to its low cost, well-defined morphology, high ion-exchange capacity (IEC), and proton conductivity comparable to Nafion ${ }^{\circledR}$ (Avilés-Barreto $\&$ Suleiman, 2013; Elabd et al., 2006). Important parameters being investigated to obtain PEMs with higher proton conductivity and low methanol permeability depend on the membrane morphology and chemical-physical interactions (Elabd et al., 2006; Kumari et al., 2018). Moreover, the water uptake and the IEC are other parameters that impact the morphology configuration in the membrane (Kusoglu et al., 2020). Sulfonated thermoplastic elastomers morphology has gained interest because the ionic structure facilitates transport and enhance the equilibrium properties. However, the nonionic microdomain provides mechanical support to the membrane (Elabd \& Hickner, 2011). An alternative to obtaining PEMs with a controlled morphology are polymer blend membranes. These types of membranes improve their proton conductivity and reduce methanol permeability (Huang et al., 2019; Jung et al., 2004). Sulfonated thermoplastic elastomers blended with well-ordered fluoroblock copolymers were studied to modify its morphology, Ion-Exchange Capacity, and water uptake (Guerrero-Gutiérrez et al., 2017). These advanced well-ordered fluoropolymers with specific structures and lower polydispersity were synthesized using Controlled radical polymerization (CRP) (Guerrero-Gutiérrez et al., 2017; Matyjaszewski, 2012).

Atom Transfer Radical Polymerization (ATRP) is a CRP technique that used an alkyl halide-like initiator, a transition metal in the lower oxidation state and a ligand to synthesize different fluoropolymers like, perfluoroalkyl ethyl methacrylate and fluoropolymers with polyether blocks, for example. Initiators for ATRP must have a halogen $(\mathrm{Br}$ or $\mathrm{Cl})$ and a functional group that can stabilize the formed radical (Jankova \& Hvilsted, 2005). These active halogen end groups can be used to extend additional polymeric chains using cationic polymerization. A pentablock copolymer of methyl methacrylate, PS, and PIB was obtained using a combination of both ATRP and cationic polymerization (Toman et al., 2005).

Fluoroblock copolymers seem to have a strong influence on the morphology and the equilibrium properties of blend membranes. Therefore, the first goal of this investigation was the synthesis of a novel fluoroblock copolymer composed of P4FS, PS and, PIB. The homo and diblock copolymer based on P4FS and PS were synthesized using ATRP. PIB was attached to the macroinitiator (P4FS-b-PS) using cationic polymerization. Furthermore, the equilibrium and thermal properties of ionic blend membranes composed of a sulfonated thermoplastic elastomer called $\mathrm{SIBS} \mathrm{SO}_{3} \mathrm{H}$ and P4FS-b-PS-PIB $\mathrm{SO}_{3} \mathrm{H}$ were investigated to determine the influence of the sulfonated fluoroblock copolymer on the Ion-Exchange Capacity, water uptake, degradation behavior, and the thermal transitions. 


\section{Materials and Methods}

\section{Materials}

Isobutylene (IB) (99.9\% purity) was acquired from Linde Gas Puerto Rico, Inc. Diethylaluminium chloride $\left(\mathrm{Et}_{2} \mathrm{AlCl}\right), 1 \mathrm{M}$ solution in hexane, AcroSeal ${ }^{\circledR}$ (Acros-Organics). Zonyl® BA-L Fluorotelomer intermediate (70 wt.\%) Mn 443 was acquired from Sigma-Aldrich. Other chemicals used include triethylamine, (Acros Organics, 99\%), 4-dimethylamino pyridine, (Acros Organics, 99\%), 2-chloropropionyl chloride, (Acros-Organics, 95\%), 2, 2'-dipyridyl-Bipy - (Acros Organics, extra pure, 99\%), calcium hydride $\left(\mathrm{CaH}_{2}\right)$ (Acros Organics, 93\%), and copper (I) chloride (Acros Organics, 99\%). All chemicals were employed as received. The monomers used included: 4-fluorostyrene (4FS) (Acros Organics 97\% stabilized with 0.1\% tert.-butylcatechol) and styrene (S) (Across Organics, 99\% inhibited with 4-tert-butyl catechol). Both 4FS and $\mathrm{S}$ were passed through an inhibitor remover (disposable column from Sigma-Aldrich). After this process, both monomers and the solvent were stored over $\mathrm{CaH}_{2}$ and then vacuum-distilled before polymerization. SIBS was purchased from Kaneka ${ }^{\circledR}$ (30 wt.\% polystyrene and $\mathrm{Mn} \sim 65,000 \mathrm{~g} / \mathrm{mol}$ ). Sulfuric acid (Sigma Aldrich, 95-98\%), acetic anhydride (Aldrich Chemical, 99+\%), hexyl alcohol (Acros Organics, 98\%, extra pure), methanol (Fisher Scientific, 99.9\%), Toluene ACS reagent (99\%) and dichloromethane (99.9\%) were acquired from Fisher Scientific.

\section{ATRP and cationic polymerization}

In a characteristic homo polymerization or copolymerization by ATRP, a Schlenk tube was charged with the initiator (esterified Zonyl ${ }^{\circledR}$ was synthesized following the procedure of a previous study (Perrier et al., 2002) or the macroinitiator (P4FS), copper chloride $(\mathrm{CuCl})$, and the 2, 2'-dipyridyl (bipy). The molar ratio of initiator:CuCl:bipy was kept 1:1:2 (Jankova \& Hvi1sted, 2003). The monomer was added, and the system was degassed three times by freezing and thawing; then heating to $110^{\circ} \mathrm{C}$ under a nitrogen atmosphere for $24 \mathrm{~h}$. Upon completion of the experiment, the polymerization mixture was diluted with THF. The solution was filtered (to remove the catalyst) and then precipitated in methanol, where the polymer appeared as a fluffy white material that was recovered after vacuum drying.
The synthesis of P4FS-B-PS-b-PIB was carried out in dichloromethane at $-41^{\circ} \mathrm{C}$ for $6 \mathrm{~h}$. The polymerization process is described in more detail elsewhere (Toman et al., 2005). A Schlenk tube was charged with the P4FS-b-PS and the IB; then the polymerization reaction was initialized with diethyl aluminum chloride. Upon completion of the experiment, the solution was precipitated in methanol. All the polymerization reactions for the homo, di, and triblock copolymers are presented in scheme 1.

\section{Characterization}

The chemical compositions of the polymers were obtained by FT-IR (Brucker Alpha Platimum-ATR). The sample was clamped on the ATR cell and all infrared spectra were collected using 64 scans, $4 \mathrm{~cm}^{-1}$ resolution, and a range of $600-4,000 \mathrm{~cm}^{-1}$. The homopolymers and the block copolymers were characterized by ${ }^{1} \mathrm{H}$ NMR, using an NMR Bruker $500 \mathrm{MHz}$ spectrometer with d-chloroform as a solvent. GPC was performed on a Waters GPC system equipped with a mixed column (PLgel $5 \mu \mathrm{m}$ MIXED-C, Varian Inc.) and a differential refractometer (BI-DNDC, Brookhaven Instruments). THF HPLC solvent was used as the mobile phase with a flow rate of $0.5 \mathrm{~mL} / \mathrm{min}$. Molecular weight distributions were obtained concerning polystyrene standards (Varian Inc.). The thermal degradation behavior for each homo, di, and triblock copolymer and the membranes was determined using TGA. A Mettler Toledo 851e instrument was used for this purpose. Polymer samples weighing approximately 5-10 mg were used in each experiment. Degradation temperatures were determined after heating the polymer samples to $800^{\circ} \mathrm{C}$ at $10^{\circ} \mathrm{C} / \mathrm{min}$ under a nitrogen atmosphere. Thermophysical properties were determined using a DSC Texas Instrument DSC Q2000. Polymer samples weighing approximately 5-10 $\mathrm{mg}$ were used in each experiment. Thermal transitions for the samples were determined after heating the polymer samples from $-80^{\circ} \mathrm{C}$ to $350^{\circ} \mathrm{C}$ at $10^{\circ} \mathrm{C} / \mathrm{min}$ under a nitrogen atmosphere.

\section{Blend Preparation, Ion Exchange Capacity (IEC) and Water Swelling}

Poly(styrene-isobutylene-styrene) (SIBS) and P4FS-b-PS-b-PIB were sulfonated using acetyl sulfate as the sulfonating agent. The sulfonation process is described in more detail elsewhere (Barreto \& Sulei- 

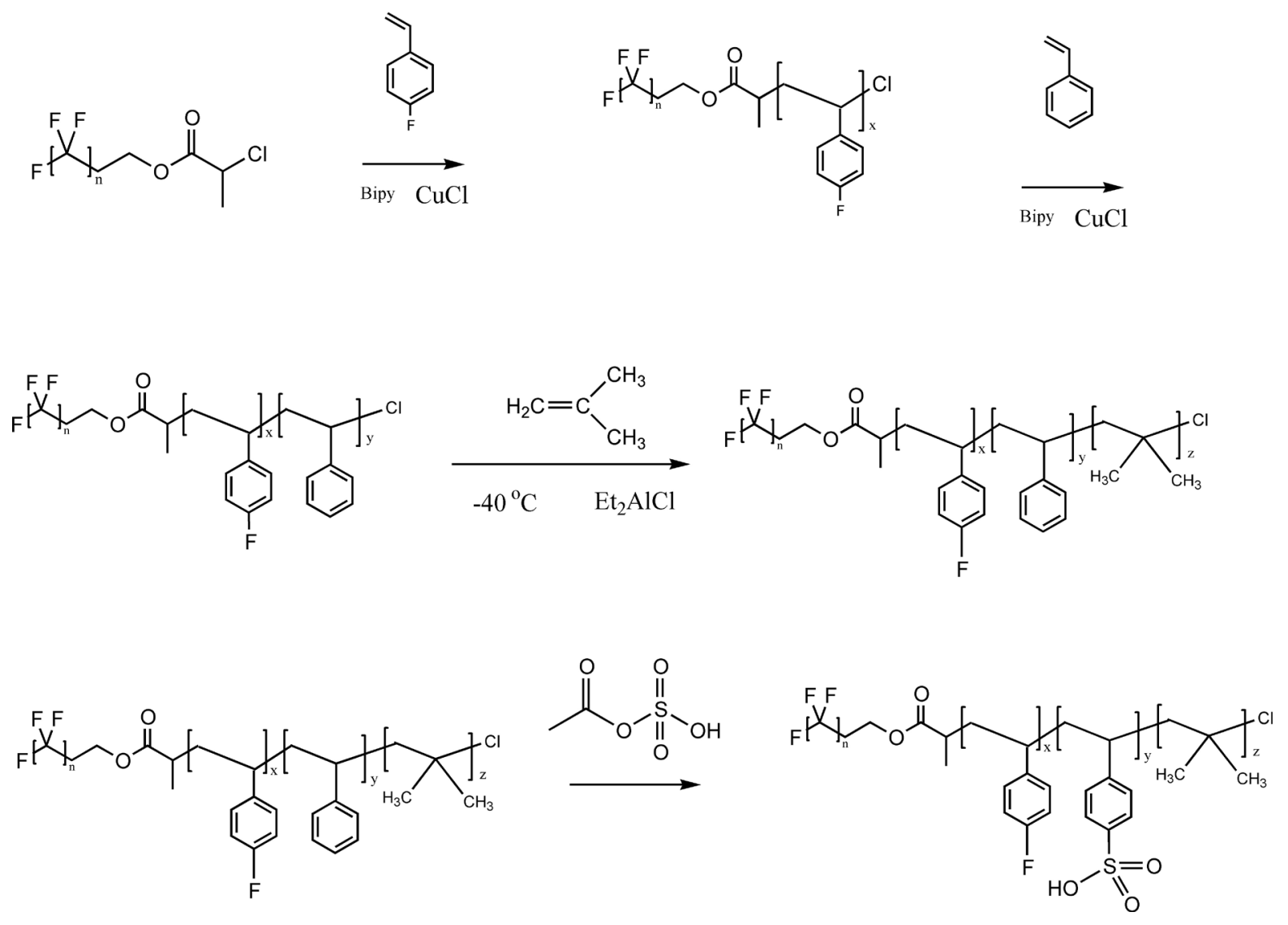

Scheme 1. Polymerization reaction for P4FS-b-PS-b-PIB and P4FS-b-PS-b-PIB SO $\mathrm{H}_{3}$

man, 2010). The preparation of physical blends consisted of mixing SIBS $\mathrm{SO}_{3} \mathrm{H}$ and P4FS-b-PS-b-PIB $\mathrm{SO}_{3} \mathrm{H}$. SIBS $\mathrm{SO}_{3} \mathrm{H}$ and the sulfonated fluoroblock copolymer were dissolved in a solution $(85 / 15)(\mathrm{v} / \mathrm{v})$ of toluene and hexyl alcohol with a polymer concentration of $5 \mathrm{wt} \%$. SIBS SO 3 H / P4FS-b-PS-b-PIB SO $\mathrm{H}_{3}$ membranes were solvent cast in Teflon ${ }^{\circledR}$ Petri dishes for $72 \mathrm{~h}$ at room temperature as the solvent evaporated; then dried at $60^{\circ} \mathrm{C}$ for $24 \mathrm{~h}$ to remove the residual solvent. Elemental Analysis (EA) was used to determine the exact amount of mole percent of sulfonated styrene in the membrane. EA was conducted by Atlantic Microlab, Norcross, Georgia. IEC was measured by immersing a specific amount of the membrane in a $1.0 \mathrm{M}$ solution of $\mathrm{NaCl}$ for $24 \mathrm{~h}$. After removing the membrane, the solution was titrated using a $0.1 \mathrm{M}$ solution of $\mathrm{NaOH}$ until the $\mathrm{pH}$ was neutral. The IEC was calculated from the moles of ion substituted divided by the initial dry mass of the membrane (Avilés-Barreto \& Suleiman, 2013). Water absorption or water swelling in the membranes was measured immersing each membrane in an excess of deionized water at $25^{\circ} \mathrm{C}$. The weight of the sample initially dried at $60^{\circ} \mathrm{C}$ for 24 hours in an oven was originally recorded, as well as the weight of the membrane after immersion in water. The weight of the wet membranes was measured after different time intervals until swelling equilibrium was reached (Ortiz-Negrón \& Suleiman, 2015).

\section{Results}

\section{Polymer characterization: molecular weight and chemical characterization}

The molecular weight of the fluoroblock copolymers was determined using GPC. P4FS was synthesized using esterified Zonyl® like initiator. The molecular weight for this polymer was $\mathrm{Mn} \sim 9,110 \mathrm{~g} / \mathrm{mol}$ with a polydispersity (PDI) of 1.48. The molecular weight 
for P4FS-b-PS and P4FS-b-PS-b-PIB was Mn 36,100 and $\mathrm{Mn} \sim 39,100 \mathrm{~g} / \mathrm{mol}$ with a PDI of 1.92 and 1.83 respectively. The molecular weight increased $8 \%$ after the cationic polymerization. The polymer composition for P4FS-b-PS-b-PIB was $1.6 \mathrm{wt} \%$ esterified Zonyl $\AA$, $6.3 \mathrm{wt} \%$ P4FS, $72.1 \mathrm{wt} \%$ PS, and $19.9 \mathrm{wt} \%$ PIB.

The chemical composition for the fluoroblock copolymers was monitored by FTIR and ${ }^{1} \mathrm{H}$ NMR. Figure 1[A] shows the FTIR spectra of P4FS. Three distinct regions of bands were observed in this figure. First, a para-substitution band of P4FS at $820 \mathrm{~cm}^{-1}$ (1) corresponds to $\mathrm{C}-\mathrm{F}$ group attached to the aromatic ring. The second region (from 2,000 to $1,667 \mathrm{~cm}^{-1}$ ) corresponds to overtone absorptions induced by the aromatic ring. The third region appeared between 1,300 and 1,000 $\mathrm{cm}^{-1}$; this is another characteristic band that corresponds to the C-F group attached to 4FS (2). Figure 1[B] shows the FTIR spectra of P4FS-b-PS. The addition of PS to the polymer backbone was confirmed by the presence of the mono-substitution band corresponding to the styrene group at $700 \mathrm{~cm}^{-1}$ (3). P4FS-b-PS-b-PIB exhibited the same bands previously observed; additionally, the vibration to the bending absorption of the $\mathrm{CH}_{3}$ group attached to PIB appeared around 1,375 $\mathrm{cm}^{-1}$ (4) (Figure 1[C]). Liquid ${ }^{1} \mathrm{H}$ NMR was employed to confirm the chemical composition of the synthesized fluoroblock copolymers. Figure 1[D] exhibits the ${ }^{1} \mathrm{H}$ NMR spectra of P4FS. This polymer presented peaks at a large chemical shift around $6.5 \mathrm{ppm}$, assigned to the typical band of the protons attached to the aromatic ring in 4FS. The peaks at 1.85 and 1.35 ppm were assigned to the methylene (- $\left.\mathrm{CH}_{2}-\right)$ and methine (-CH-) absorptions in 4FS. Figure 1[E] shows the ${ }^{1} \mathrm{H}$ NMR spectra for P4FS-b-PS; this spectrum presented an additional absorption around $7 \mathrm{ppm}$ that represents the protons attached to the aromatic ring in PS. One additional peak appeared in P4FS-b-PS-b-PIB concerning P4FS-b-PS at 1 ppm (Figure 1[F]). This absorption is a characteristic chemical shift that corresponds to the methyl group (- $\left.\mathrm{CH}_{3}-\right)$ attached to PIB. Both FT-IR and Liquid ${ }^{1} \mathrm{H}$ NMR spectra confirm the chemical composition of the synthesized polymers using ATRP and cationic polymerization.

\section{Polymer characterization: thermal behavior}

The thermal degradation for the fluoroblock copolymers was obtained by TGA. P4FS (Figure 2[A]) presented two different degradations. The first degradation occurred at $177.96^{\circ} \mathrm{C}$ with a weight loss percent of $7.35 \%$. The polymer backbone remained constant until the second degradation range from $375^{\circ} \mathrm{C}$ to $440^{\circ} \mathrm{C}$. The weight loss percent for this degradation was $92.65 \%$. The thermal stability of P4FS-b-PS is shown in Figure 2[B]. This polymer exhibited two degradation temperatures at $178^{\circ} \mathrm{C}$ and $417^{\circ} \mathrm{C}$ with a weight loss of $5 \%$ and $95 \%$ respectively. Figure $2[\mathrm{C}]$ exhibits the degradation of P4FS-b-PS-PIB. The addition of PIB into the polymeric chain adversely affected the thermal stability of P4FS-b-PS. The polymer suffered thermal degradation below $110^{\circ} \mathrm{C}$, and the re-
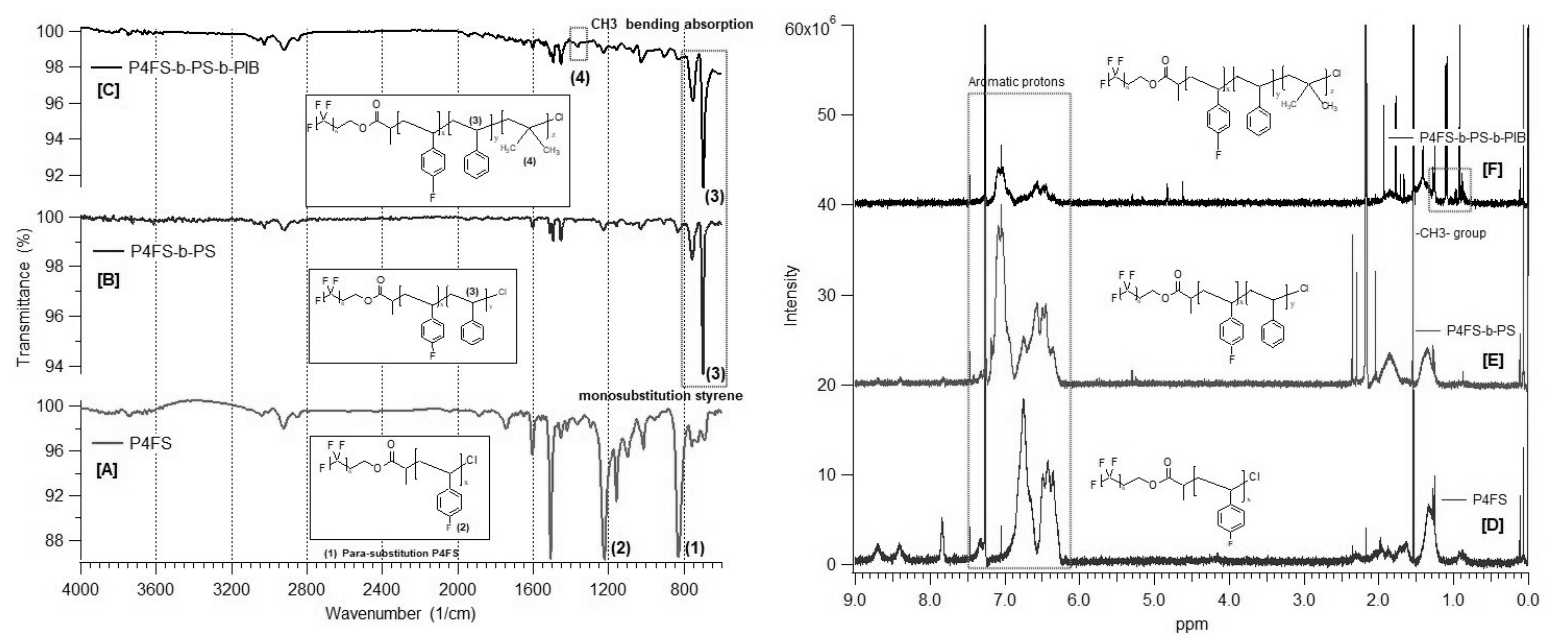

Figure 1. FTIR spectra for P4FS [A], P4FS-b-PS [B], and P4FS-b-PS-b-PIB [C]. ${ }^{1} \mathrm{H}$ NMR spectra for P4FS [D], P4FSb-PS [E], and P4FS-b-PS-b-PIB [F]. 


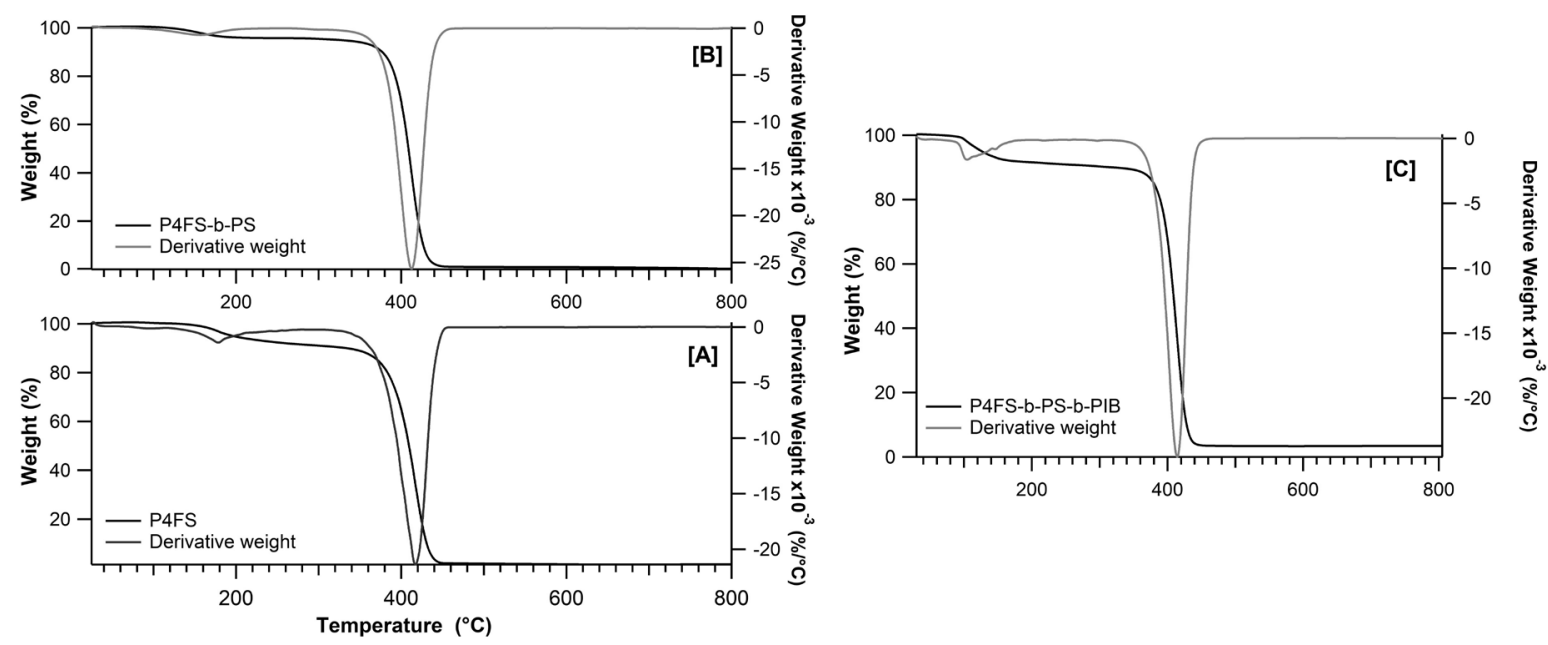

Figure 2. Thermal stability for P4FS [A], P4FS-b-PS [B] and P4FS-b-PS-b-PIB [C].

maining polymer chain degraded at $417^{\circ} \mathrm{C}$. The weight loss step of PIB was overlapped with all the P4FS-b-PS polymeric chains.

\section{Polymer blend characterization: sulfonation level, Ion-Exchange Capacity (IEC), water uptake and thermal behavior}

The sulfonation level was calculated from the elemental analysis results. The sulfonation level for SIBS $\mathrm{SO}_{3} \mathrm{H}$ was $84 \%$. The addition of P4FS-b-PS-bPIB $\mathrm{SO}_{3} \mathrm{H}$ to SIBS $\mathrm{SO}_{3} \mathrm{H}$ increased the sulfonation level from 84 to $93 \%$. The addition of the sulfonated fluoroblock copolymer also affected the IEC. The IEC indicates the ion-exchangeable sites available per gram of membrane. The IEC for SIBS $\mathrm{SO}_{3} \mathrm{H}$ was $1.84 \mathrm{meq} / \mathrm{g}$; however, the blend membrane increased 36\% (2.50 me$\mathrm{q} / \mathrm{g}$ ) concerning $\mathrm{SIBS} \mathrm{SO}_{3} \mathrm{H}$. The water uptake represents the water absorbed by the membrane. $\mathrm{SIBS} \mathrm{SO}_{3} \mathrm{H}$ exhibited a water uptake of $608 \%$. The polymeric blend membrane exhibited different behavior; the membrane started to dissolve after 5 min submerged in water.

Figure 3[A] shows the thermal behavior for the SIBS $\mathrm{SO}_{3} \mathrm{H}$ membrane. This membrane exhibited four degradation temperatures. The first at $50-100^{\circ} \mathrm{C}$; the second degradation at $245^{\circ} \mathrm{C}$, the third degradation at $419^{\circ} \mathrm{C}$, and the last degradation at $525^{\circ} \mathrm{C}$. Figure $3[\mathrm{~B}]$ shows the degradation curve for the $\mathrm{SIBS}_{3} \mathrm{H}$ / P4FS-b-PS-b-PIB $\mathrm{SO}_{3} \mathrm{H}$ membrane. This membrane exhibited one region that remained unchanged concerning $\mathrm{SIBS} \mathrm{SO}_{3} \mathrm{H}\left(419^{\circ} \mathrm{C}\right)$. Nevertheless, at $203^{\circ} \mathrm{C}$ and $274^{\circ} \mathrm{C}$ were observed two additional weight losses; moreover, the degradation at $524^{\circ} \mathrm{C}$ exhibited a different degradation trend. Figure $3[\mathrm{C}]$ exhibits the DSC curve for SIBS $\mathrm{SO}_{3} \mathrm{H}$. This membrane exhibited two endothermic peaks at $140^{\circ} \mathrm{C}$ at $177^{\circ} \mathrm{C}$. The first and second endothermic peaks require 1.58 and 305 $\mathrm{J} / \mathrm{g}$, respectively. The incorporation of P4FS-b-PS-PIB $\mathrm{SO}_{3}$ to SIBS $\mathrm{SO}_{3} \mathrm{H}$ presented a difference in both the energy and the temperature required to produce the endothermic transitions. The first endothermic transition shifted to a higher temperature $\left(147^{\circ} \mathrm{C}\right)$; however, the second transitions moved towards lower temperature $\left(168^{\circ} \mathrm{C}\right)$ and requires $1.98 \mathrm{~J} / \mathrm{g}$. Interestedly, the energy required to produce both transitions increased by 25.31 and $25.24 \%$ respectively.

\section{Discussion}

\section{Polymer characterization: thermal behavior}

The thermal behavior for the fluoropolymers was obtained using TGA. The first degradation of P4FS at $177.96^{\circ} \mathrm{C}$ with a weight loss percent of $7.35 \%$ corresponds to esterified Zonyl®. PS polymerized using esterified Zonyl® produces degradation at a similar temperature (Guerrero-Gutiérrez et al., 2015). The second degradation range $\left(375-440^{\circ} \mathrm{C}\right)$ corresponds to the polymer backbone. P4PS-b-PS (Figure 2[B]) exhibited similar degradation range temperatures than P4FS. The degradation range temperature of PS is located between $375-450^{\circ} \mathrm{C}$ (Seleem et al., 2017). 

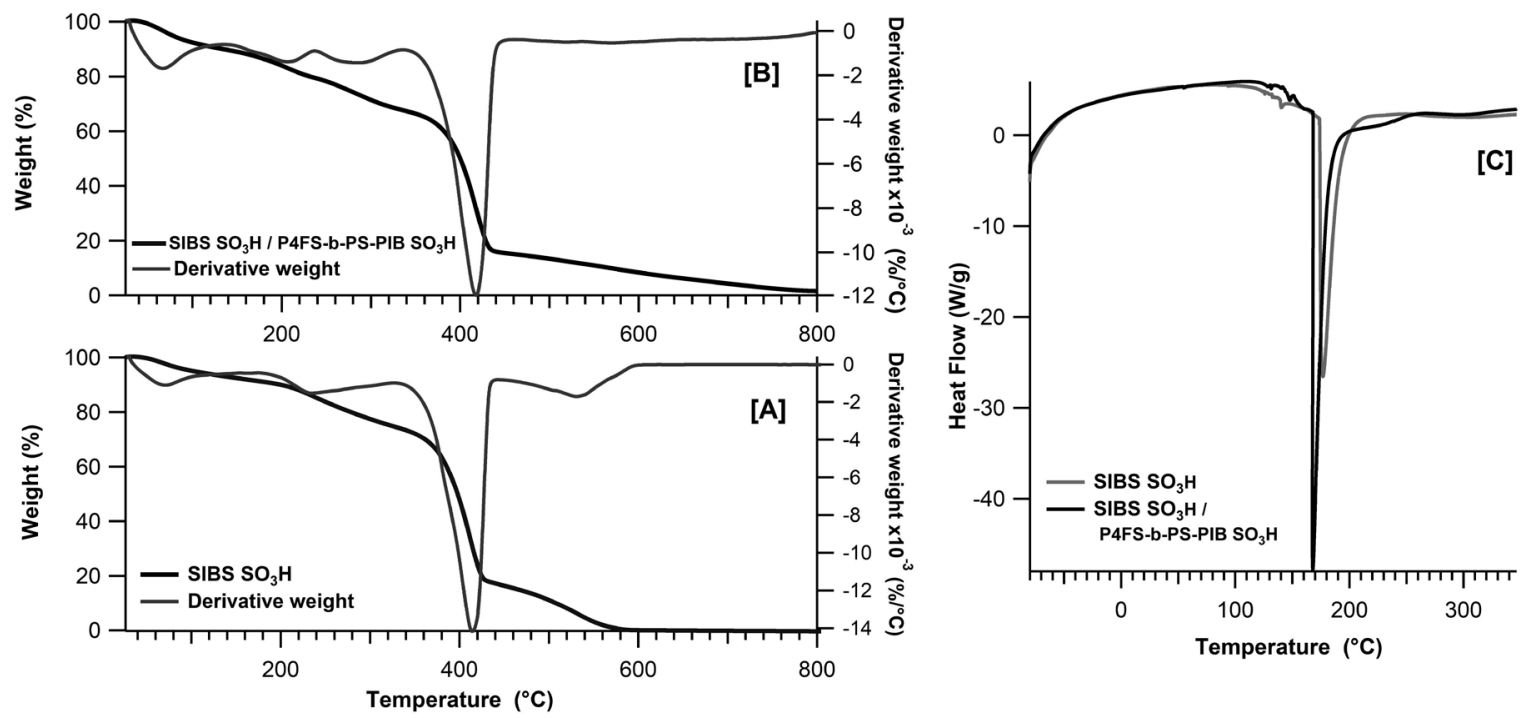

Figure 3. Thermal stability for SIBS $\mathrm{SO}_{3} \mathrm{H}[\mathrm{A}]$ and $\mathrm{SIBS} \mathrm{SO}_{3} \mathrm{H} / \mathrm{P} 4 \mathrm{FS}-\mathrm{b}-\mathrm{PS}-\mathrm{b}-\mathrm{PIB} \mathrm{SO}_{3} \mathrm{H}[\mathrm{B}]$ membranes. DSC curve for SIBS $\mathrm{SO}_{3} \mathrm{H}$ and SIBS $\mathrm{SO}_{3} \mathrm{H} / \mathrm{P} 4 \mathrm{FS}-\mathrm{b}-\mathrm{PS}-\mathrm{b}-\mathrm{PIB} \mathrm{SO}_{3} \mathrm{H}[\mathrm{C}]$.

Consequently, the weight loss of PS was overlapped with P4FS degradation. The weight loss step of PIB also was overlapped with all the P4FS-b-PS chains (Figure 2[C]). Previous studies report that the weight loss of block copolymers composed of PS and PIB is indistinguishable from each other (Avilés-Barreto \& Suleiman, 2013; Suleiman et al., 2007).

\section{Polymer blend characterization: sulfonation level, Ion-Exchanged Capacity (IEC), water uptake and thermal behavior}

The degradation behavior for the membranes was obtained using TGA. SIBS $\mathrm{SO}_{3} \mathrm{H}$ membrane exhibited four degradation ranges. The first at $50-100^{\circ} \mathrm{C}$ corresponds to water absorbed in the membrane; the second degradation region at $245^{\circ} \mathrm{C}$ represents the sulfonic group, and the third degradation at $419^{\circ} \mathrm{C}$ represents the polymer backbone degradation (Suleiman et al., 2007). Figure $3[\mathrm{~B}]$ shows the degradation curve for the

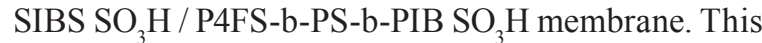
membrane exhibited one region that remained unchanged concerning SIBS $\mathrm{SO}_{3} \mathrm{H}$ at $419^{\circ} \mathrm{C}$. Nevertheless, at $203^{\circ} \mathrm{C}$ and $274^{\circ} \mathrm{C}$ were observed two additional weight losses. These results suggest that different sulfonic domains coexist in the same polymer membrane. Additionally, ionic interactions with the sulfonic group suggest a different trend in weight loss at higher temperatures $\left(525^{\circ} \mathrm{C}\right)$ in sulfonated SIBS membranes (Avilés-Barreto \& Suleiman, 2013).

Figure $3[\mathrm{C}]$ presents the DSC curve for SIBS $\mathrm{SO}_{3} \mathrm{H}$. This membrane exhibited two endothermic peaks at 140 at $177^{\circ} \mathrm{C}$. The first endothermic peak $(1.58 \mathrm{~J} / \mathrm{g})$ is related to the transition for the ionic group and the second peak $(305 \mathrm{~J} / \mathrm{g})$ to the transition to the crystalline regions associated with a new configuration for the ionic domain and the polymeric backbone (Guerrero-Gutiérrez et al., 2015). The incorporation of P4FS-b-PS-b-SO $\mathrm{S}_{3} \mathrm{H}$ modified in both the energy and the temperature required to produce endothermic transitions. The endothermic transitions for the ionic group shifted towards a higher temperature $\left(147^{\circ} \mathrm{C}\right)$. However, the endothermic transition for the crystalline region shifted towards a lower temperature $\left(168^{\circ} \mathrm{C}\right)$. The changes in temperature are related to the energy needed to overcome the crystalline bonding forces and changes in the molecular conformation of the chains in the polymer (Rosen, 1993) and confirm the differences in the ionic domain configuration shown above with the thermogravimetric results. SIBS $\mathrm{SO}_{3} \mathrm{H}$ membranes with ion exchange capacity above $1 \mathrm{meq} / \mathrm{g}$ exhibit a nonperiodic morphology in the SAXS profile (Elabd et al., 2006). The addition of homo fluoropolymers into $\mathrm{SIBS} \mathrm{SO}_{3} \mathrm{H}$ membranes changed its nonperiodic morphology; therefore, the ionic domain increased by 10.14\% (Guerrero-Gutiérrez et al., 2015). This study 
provides valuable insight into the synergistic effects of the sulfonated trifluoroblock copolymer and the equilibrium properties of the blend membrane with an ion exchange capacity of $2.50 \mathrm{meq} / \mathrm{g}$. However, the ionic domain size quantification induced by the P4FSb-PS-b-PIB $\mathrm{SO}_{3} \mathrm{H}$ addition is out of the scope of this research.

The capacity of the membrane to absorbed water is also related to the IEC (Ruiz-Colón et al., 2018). SIBS $\mathrm{SO}_{3} \mathrm{H}$ exhibits a water swelling of $608 \%$. Interestingly, SIBS $\mathrm{SO}_{3} \mathrm{H} / \mathrm{P} 4 \mathrm{FS}-b-\mathrm{PS}-b-\mathrm{PIB} \mathrm{SO}_{3} \mathrm{H}$ membrane absorbed a high amount of water. The membrane starts to dissolve after five minutes in water. This behavior was induced by a high sulfonation level and ion-exchanged capacity. Polymer membranes with similar sulfonation levels and IEC also dissolved in water (Pérez-Pérez \& Suleiman, 2015). Moreover, the polymer composition of the fluoroblock copolymers could play a significant role in the water uptake and IEC. The addition of electron-withdrawing hydrophobic group (i.e., P4FS) to the polymer could affect the water uptake and IEC in a polymer electrolyte membrane (Shimura et al., 2008). Furthermore, a non-ionic block (PIB) can be designed to be a barrier for hydrophilic components and the block copolymer ionomer (sulfonated PS) to self-assemble into unique nanostructured morphology that may lead to different equilibrium and thermal properties (Elabd et al., 2003). An additional study about the effect of the chemical fluoroblock polymer composition could determine the role of each block separately on the thermal and equilibrium properties in the blend membrane.

\section{Conclusion}

A novel fluoro triblock copolymer was successfully synthesized using ATRP and cationic polymerization. The incorporation of P4FS-b-PS-bPIB $\mathrm{SO}_{3} \mathrm{H}$ into $\mathrm{SIBS}_{3} \mathrm{SO}_{3} \mathrm{H}$ possess a significant impact on the thermal stability of the membrane. Additionally, these modifications induced higher water absorption into the membrane. A morphological study using SAXS could confirm the new configuration for the ionic domain induced by the addition of the sulfonated fluoroblock copolymer into $\mathrm{SIBS} \mathrm{SO}_{3} \mathrm{H}$. Additionally, an AFM and electronic microscope analysis in dry and wet conditions need to be done to analyze the morphological changes in the membrane and its impact on the equilibrium properties. Moreover, proton conductivity is necessary to understand the transport properties in
PEMs fuel cells; however, a crosslinking study is required first due to the high solubility of the membrane in water. Therefore, the addition of the sulfonated fluoroblock copolymer modified the crystalline domains, which influenced the EIC and the water uptake. These results would have significant implications on the design of blend membranes for PEMs applications.

\section{References}

Ahmad, S., \& Ahmed, S. K. M. (2014). Application of membrane technology in food processing. In A. Malik, Z. Erginkaya, S. Ahmad \& H. Erten (Eds.), Food Processing: Strategies for Quality Assessment (pp. 379-394). Springer New York. https://doi.org/10.1007/978-1-4939-1378-7_15

Alaswad, A., Palumbo, A., Dassisti, M., \& Olabi, A. G. (2016). Fuel cell technologies, applications, and state of the art. A reference guide. In Reference Module in Materials Science and Materials Engineering. Elsevier. https://doi.org/10.1016/ b978-0-12-803581-8.04009-1

Avilés-Barreto, S. L., \& Suleiman, D. (2013). Transport properties of sulfonated poly (styreneisobutylene-styrene) membranes with counter-ion substitution. Journal of Applied Polymer Science, 129(4), 2294-2304. http://dx.doi.org/10.1002/ app.38952

Barreto, S. M. A., \& Suleiman, D. (2010). Synthesis and characterization of sulfonated poly(styreneisoprene-styrene): Effects of linear vs. branched morphology and counter-ion substitution. Journal of Membrane Science, 362(1-2), 471-477. http:// dx.doi.org/10.1016/j.memsci.2010.06.061

Elabd, Y. A., \& Hickner, M. A. (2011). Block copolymers for fuel cells. Macromolecules, 44(1), 1-11. https://doi.org/10.1021/ma101247c

Elabd, Y. A., Napadensky, E., Sloan, J. M., Crawford, D. M., \& Walker, C. W. (2003). Triblock copolymer ionomer membranes: Part I. Methanol and proton transport. Journal of Membrane Science, 217(1-2), 227-242. https://doi.org/http://dx.doi. org/10.1016/S0376-7388(03)00127-3

Elabd, Y. A., Napadensky, E., Walker, C. W., \& Winey, K. I. (2006). Transport properties of sulfonated poly(styrene-b-isobutylene-b-styrene) triblock copolymers at high ion-exchange capacities. 
Macromolecules, 39(1), 399-407. https://doi. org $/ 10.1021 / \mathrm{ma} 051958 \mathrm{n}$

Guerrero-Gutiérrez, E. M. A., Pérez-Pérez, M., Newbloom, G. M., Pozzo, L. D., \& Suleiman, D. (2017). Effect of block composition on the morphology and transport properties of sulfonated fluoroblock copolymer blend membranes. Polymer Engineering and Science, 57(11), 1262-1272. https://doi.org/10.1002/ pen. 24508

Guerrero-Gutiérrez, E. M. A., Pérez-Pérez, M., \& Suleiman, D. (2015). Synthesis and characterization of sulfonated fluorinated block copolymer membranes with different esterified initiators for DMFC applications. Journal of Applied Polymer Science, 132(23). https://doi. org/10.1002/app.42046

Huang, Q., Cheng, Y., Zhang, S., Liu, H., \& Liao, H. (2019). Blend proton exchange membranes with high performance based on sulfonated poly(arylene ether phosphine oxide)s and poly(vinylidene fluoride). Journal of Materials Science, 54(6), 5176-5186. https://doi.org/10.1007/ s10853-018-03202-z

Jankova, K., \& Hvilsted, S. (2003). Preparation of Poly(2,3,4,5,6-pentafluorostyrene) and block copolymers with styrene by ATRP. Macromolecules, 36(5), 1753-1758. https://doi. org $/ 10.1021 / \mathrm{ma} 021039 \mathrm{~m}$

Jankova, K., \& Hvilsted, S. (2005). Novel fluorinated block copolymer architectures fuelled by atom transfer radical polymerization. Journal of Fluorine Chemistry, 126(2), 241-250. https://doi. org/10.1016/j.jfluchem.2004.11.002

Jung, B., Kim, B., \& Yang, J. M. (2004). Transport of methanol and protons through partially sulfonated polymer blend membranes for direct methanol fuel cell. Journal of Membrane Science, 245(1-2), 61-69. https://doi.org/10.1016/j. memsci.2004.07.016

Kraytsberg, A., \& Ein-Eli, Y. (2014). Review of advanced materials for proton exchange membrane fuel cells. Energy \& Fuels, 28(12), 7303-7330. https://doi.org/10.1021/ef501977k

Kumari, M., Sodaye, H. S., Sen, D., \& Bindal, R. C. (2018). Properties and morphology studies of proton exchange membranes based on cross- linked sulfonated poly (ether ether ketone) for electrochemical application: Effect of crosslinker chain length. Solid State Ionics, 316, 75-84. https://doi.org/10.1016/j.ssi.2017.12.027

Kusoglu, A., Vezzù, K., Hegde, G. A., Nawn, G., Motz, A. R., Sarode, H. N., Haugen, G. M., Yang, Y., Seifert, S., Yandrasits, M. A., Hamrock, S., Maupin, C. M., Weber, A. Z., Di Noto, V., \& Herring, A. M. (2020). Transport and morphology of a proton exchange membrane based on a doubly functionalized perfluorosulfonic imide side chain perflourinated polymer. Chemistry of Materials, 32(1), 38-59. https://doi.org/10.1021/ acs.chemmater. 8 b05012

Kusoglu, A., \& Weber, A. Z. (2017). New insights into perfluorinated sulfonic-acid ionomers. Chemical Reviews, 117(3), 987-1104. https://doi.org/10.1021/ acs.chemrev.6b00159

Madaeni, S. S., Ghaemi, N., \& Rajabi, H. (2015). Advances in polymeric membranes for water treatment. In A. Basile, A. Cassano, \& N. K. Rastogi (Eds.), Advances in Membrane Technologies for Water Treatment (Part One, pp. 3-41). Woodhead Publishing. https://doi. org/10.1016/B978-1-78242-121-4.00001-0

Mauritz, K. A., \& Moore, R. B. (2004). State of understanding of Nafion. Chemical Reviews, 104(10), 4535-4586. https://doi.org/10.1021/ cr0207123

Matyjaszewski, K. (2012). Atom transfer radical polymerization (ATRP): Current status and future perspectives. Macromolecules, 45(10), 4015-4039. https://doi.org/10.1021/ma3001719

Ortiz-Negrón, A., \& Suleiman, D. (2015). The effect of $\mathrm{TiO}_{2}$ nanoparticles on the properties of sulfonated block copolymers. Journal of Applied Polymer Science, 132(41), 1-17. https://doi.org/10.1002/ app.42651

Peighambardoust, S. J., Rowshanzamir, S., \& Amjadi, M. (2010). Review of the proton exchange membranes for fuel cell applications. International Journal of Hydrogen Energy, 35(17), 9349-9384. https://doi.org/10.1016/j. ijhydene.2010.05.017

Pérez-Pérez, M., \& Suleiman, D. (2015). Transport properties of sulfonated poly(ether ether ketone) membranes with counter-ion substitution. 
Journal of Membrane Science, 493, 414-427. https://doi.org/10.1016/j.memsci.2015.06.017

Pérez-Pérez, M., \& Suleiman, D. (2016). Effect of block composition on the morphology, hydration, and transport properties of sulfonated PS-bPEGPEM-b-PS. Journal of Applied Polymer Science, 133(48), 1-12. https://doi.org/10.1002/ app. 44343

Perrier, S., Jackson, S. G., Haddleton, D. M., \& Ameduri, B. (2002). Preparation of fluorinated methacrylic copolymers by copper mediated living radical polymerization. Tetrahedron, 58, 4053-4059. https://doi.org/10.1016/S00404020(02)00274-0

Rosen, S. (1993). Fundamental Principles of Polymeric Materials $\left(2^{\text {nd }}\right)$. Wiley Interscience Publication.

Ruiz-Colón, E., Pérez-Pérez, M., \& Suleiman, D. (2018). Influence of carboxylated and phosphonated single-walled carbon nanotubes on the transport properties of sulfonated poly(styrene-isobutylenestyrene) membranes. Journal of Polymer Science, Part A: Polymer Chemistry, 56(21), 2475-2495. https://doi.org/10.1002/pola.29222

Santoro, C., Arbizzani, C., Erable, B., \& Ieropoulos, I. (2017). Microbial fuel cells: From fundamentals to applications. A review. Journal of Power Sources, 356, 225-244. https://doi.org/10.1016/j. jpowsour.2017.03.109

Seleem, S., Hopkins, M., Olivio, J., \& Schiraldi, D. A. (2017). Comparison of thermal decomposition of polystyrene products vs. bio-based polymer aerogels. Ohio Journal of Science, 117(2), 50-60. https://doi.org/10.18061/ojs.v117i2.5828

Suleiman, D., Napadensky, E., Sloan, J. M., \& Crawford, D. M. (2007). Thermogravimetric characterization of highly sulfonated poly(styrene-isobutylene-styrene) block copolymers: Effects of sulfonation and counterion substitution. Thermochimica Acta, 460(1-2), 35-40. https://doi.org/10.1016/j.tca.2005.01.030
Shimura, T., Miyatake, K., \& Watanabe, M. (2008). Poly(arylene ether) ionomers containing sulfofluorenyl groups: Effect of electronwithdrawing groups on the properties. European Polymer Journal, 44(12), 40544062. https://doi.org/http://dx.doi.org/10.1016/j. eurpolymj.2008.09.017

Singh, R. (2015). Chapter 1-Introduction to Membrane Technology. In R. Singh (Ed.), Membrane Technology and Engineering for Water Purification (2 $2^{\text {nd }}$, pp. 1-80). ButterworthHeinemann. https://doi.org/10.1016/B978-0-44463362-0.00001-X

Toman, L., Janata, M., Spěváček, J., Vlček, P., Látalová, P., Sikora, A., \& Masař, B. (2005). Synthesis of methyl methacrylate, styrene, and isobutylene multiblock copolymers using atom transfer and cationic polymerization. Journal of Polymer Science Part A: Polymer Chemistry, 43(17), 38233830. https://doi.org/10.1002/pola.20884

Xie, H., Tao, D., Xiang, X., Ou, Y., Bai, X., \& Wang, L. (2015). Synthesis and properties of highly branched star-shaped sulfonated block poly(arylene ether)s as proton exchange membranes. Journal of Membrane Science, 473(0), 226-236. https://doi.org/10.1016/j. memsci.2014.09.015

Ye, H., Li, D., Ye, X., Zheng, Y., Zhang, Z., Zhang, H., \& Chen, Z. (2019). An adjustable permeation membrane up to the separation for multicomponent gas mixture. Scientific Reports, 9(1), 1-8. https://doi.org/10.1038/s41598-01943751-0 